\title{
Non-psychiatrist prescriptions within the Brazilian National Health System represents a risk to patients in the use of psychotropic pharmacotherapies
}

\author{
As prescrições não psiquiátricas no Sistema Nacional de Saúde brasileiro representam um risco \\ para os pacientes no uso de farmacoterapias psicotrópicas
}

Las prescripciones no psiquiatras dentro del Sistema Nacional de Salud brasileño representan riesgo a los pacientes en el uso de farmacoterapias psicotrópicas

Guilherme Vaz de Melo Trindade ORCID: https://orcid.org/0000-0001-7585-3049 National University of Ireland, Galway, Ireland E-mail: guivmt@gmail.com

Diego Alexandre Gomes Sousa ORCID: https://orcid.org/0000-0002-6031-7283 Federal University of São João Del Rei, Brazil E-mail: diego.sousa.med@gmail.com

Ana Elisa Santos Duarte ORCID: https://orcid.org/0000-0003-2010-4504 Federal University of São João Del Rei, Brazil E-mail: anaesd@ hotmail.com

Jássia Lopes Freitas da Silveira ORCID: https://orcid.org/0000-0003-1910-3926 Federal University of São João Del Rei, Brazil E-mail: jassialopes@hotmail.com

Roberto Lazzarini de Oliveira ORCID: https://orcid.org/0000-0001-6270-8192 Federal University of São João Del Rei, Brazil E-mail: betolazzarin@hotmail.com

Laryssa de Cássia Ferreira ORCID: https://orcid.org/0000-0003-4605-3493 Federal University of São João Del Rei, Brazil E-mail: cf.lara2015@gmail.com

Pedro Polastri Lima Peixoto ORCID: https://orcid.org/0000-0001-5132-1793 Federal University of São João Del Rei, Brazil E-mail: polastri.lp@gmail.com

Angelita Cristine de Melo ORCID: https://orcid.org/0000-0002-2714-7171 Federal University of São João Del Rei, Brazil E-mail: angelitamelo@ufsj.edu.br

\begin{abstract}
This cross-sectional study collected data from the Brazilian National Health System (NHS) patients' that filled their psychotropic prescriptions in NHS owned pharmacies. The study aimed to identify oversights in psychotropic prescriptions leading to insecure therapeutic. Patients in use of at least one psychotropic drug in 12 months were identified by a retrospective data search and considered for the study. After examining 15,001 patients in use of psychotropic medicines, 7,440 met the inclusion criterion. The majority of patients were women $(67.1 \%), 54.2 \%$ of prescriptions analyzed over the studied period presented multiple medicines including one psychotropic, and $54.7 \%$ cursing with psychotropic monotherapy. In $92.7 \%$ of cases, only one medicine was dispensed and prescriptions from psychiatrists represented only $17.6 \%$ of cases. In terms of safety, $9.5 \%$ of patients had at least one potential drug interaction of clinical significance, and $71.5 \%$ of elder patients had at least one drug that was potentially inappropriate for their age group use. These findings suggest urgency in integrating patients' medical records information to pharmacotherapy history at the pharmacy computer technology applied for dispensing, reducing harm to patients in the use of psychotropic drugs.
\end{abstract}

Keywords: Psychotropic drugs; Prescription; Drug interaction; Medical records; Pharmacotherapy. 


\begin{abstract}
Resumo
Este estudo transversal coletou dados de pacientes do Sistema Único de Saúde (SUS) que preencheram suas prescrições de psicotrópicos em farmácias próprias do SUS. O estudo teve como objetivo identificar descuidos nas prescrições de psicotrópicos levando a uma terapêutica insegura. Pacientes em uso de pelo menos um psicofármaco em 12 meses foram identificados por meio de busca retrospectiva de dados e considerados para o estudo. Após o exame de 15.001 pacientes em uso de psicofármacos, 7.440 atenderam ao critério de inclusão. A maioria dos pacientes era do sexo feminino $(67,1 \%), 54,2 \%$ das prescrições analisadas no período estudado apresentavam múltiplos medicamentos incluindo um psicotrópico e 54,7\% cursando com monoterapia psicotrópica. Em 92,7\% dos casos, foi dispensado apenas um medicamento e as prescrições de psiquiatras representaram apenas 17,6\% dos casos. Em termos de segurança, 9,5\% dos pacientes apresentavam pelo menos uma potencial interação medicamentosa com significância clínica e 71,5\% dos pacientes idosos tinham pelo menos um medicamento potencialmente inapropriado para o uso em sua faixa etária. Esses achados sugerem urgência na integração das informações dos prontuários dos pacientes ao histórico de farmacoterapia da tecnologia de informática da farmácia aplicada à dispensação, reduzindo os danos aos pacientes no uso de psicofármacos.
\end{abstract}

Palavras-chave: Psicotrópicos; Prescrição; Interação medicamentosa; Registros médicos; Farmacoterapia.

\title{
Resumen
}

Este estudio transversal recopiló datos de pacientes del Sistema Nacional de Salud de Brasil (NHS) que surtieron sus recetas de psicotrópicos en farmacias propiedad del NHS. El estudio tuvo como objetivo identificar descuidos en las prescripciones psicotrópicas que conducen a una terapéutica insegura. Los pacientes en uso de al menos un fármaco psicotrópico en 12 meses fueron identificados mediante una búsqueda de datos retrospectiva y considerados para el estudio. Después de examinar a 15.001 pacientes en el uso de medicinas psicotrópicos, 7.440 cumplieron el criterio de inclusión. La mayoría de los pacientes eran mujeres (67,1\%), el 54,2\% de las prescripciones analizadas durante el período estudiado presentaban múltiples medicamentos, incluido uno psicotrópico, y el 54,7\% maldiciones con monoterapia psicotrópica. En el 92,7\% de los casos, solo se dispensa un medicamento y las prescripciones de psiquiatras representan solo el 17,6\% de los casos. En términos de seguridad, el 9,5\% de los pacientes tenían al menos una interacción farmacológica potencial de importancia clínica, y el 71,5\% de los pacientes de edad avanzada tenían al menos un fármaco que era potencialmente inapropiado para el uso de su grupo de edad. Estos hallazgos sugieren la urgencia de integrar la información de los registros médicos de los pacientes al historial de farmacoterapia en la tecnología informática de la farmacia aplicada para la dispensación, lo que reduce el daño a los pacientes en el uso de fármacos psicotrópicos.

Palabras clave: Fármacos pscicotrópicos; Prescripción; Interacción; Registros médicos; Farmacoterapia.

\section{Introduction}

Recently Neurological disorders have emerged as a public health challenge, with one billion people affected worldwide. Neurological disorders affect people in all countries, irrespective of age, sex, education, or income. Neurological and psychiatric diseases (NPDs) are a group of conditions that includes, among others symptoms, mood changes, neurotic and stress-related or somatoform disorders, mental and behavioural disorders due to psychoactive substance use, schizophrenia, dementia, and epilepsy (WHO, 2021). These conditions represent a wide spectrum of manifestations and treatments performed mostly on an outpatient basis, according to the deinstitutionalization program (Chow, Priebe, 2013; Guerra et al., 2013). NPDs are associated with high social costs and contribute significantly to the burden of chronic, non-communicable diseases (NCDs) and the potential years of life lost to disability, surpassing cancer as well as cardiovascular, respiratory, and other chronic diseases (Bianchi, Bianchini, Scanavacca, 2011; Guerra et al., 2013; Schmidt et al., 2011).

The historical and globalized stigma of the use of psychotropic medicines plays in society must be understood and requires that patients are looked after while treating until they are adherent to pharmacotherapy. More importantly, efforts are needed to make them understand in-depth details on the use, main reactions, and relevant side effects. Each ethnic group accepts those treatments differently so that clinicians and pharmacists are urged to be ready and assist patients who will initiate treatments with those medicines (Alarcon et al., 2019).

Old age is often associated with several long-term, chronic diseases increasing medication demand and creating polypharmacy scenarios on pharmacotherapy. Among the chronic conditions in geriatric care, mental health conditions such as depression, dementia associated with behavior and psychological symptoms, psychosis, anxiety, and insomnia are common 
(Azermai et al., 2011). Most medicines used to treat central nervous system disorders; such as psychotropics, antipsychotics, antidepressants, benzodiazepines, antiepileptics, and anti parkinsonism are associated with adverse drug events in older adults (Hasan et al., 2019).

Pharmacotherapy is a major therapeutic resource used for the management of NPDs, and its introduction had a great impact on patients' clinical management and quality of life, avoiding hospitalization, and reducing the length of stay in hospital beds (Bianchi, Bianchini, Scanavacca, 2011; Chow, Priebe, 2013; Guerra et al., 2013). An increase in the consumption of these medications is associated with the increased frequency of diagnosis, the introduction of new psychiatric drugs, and new clinical use for the existing ones (Hedenrud, Svensson, Wallerstedt, 2013; Rodrigues, Facchini, Lima, 2019). Studies between 2003 and 2013 in Brazil have identified a prevalence of psychotropic drug use ranging from 6.5 to 9.9\% (Quintana et al., 2013; Rocha, Werlang, 2013; Rodrigues, Facchini, Lima, 2019).

Psychiatric disorders can be clinically managed with a wide selection of psychotropic pharmacotherapy launched in the past two decades, the development of newer drugs as Selective Serotonin Reuptake Inhibitors and atypical antipsychotics have radically modified the therapy protocols (Thakkar et al., 2013). Despite the importance of psychotropic drugs for controlling NPDs, their use should be cautionary as it can cause addiction, risking people's health state (Lader, Tylee, Donoghue, 2009; Wagner, Andrade, 2010; Bianchi, Bianchini, Scanavacca, 2011; Klasco RK, 2017).

Psychotropic drug toxicity often leads to medication errors that compromise the effectiveness and safety of the selected pharmacotherapy with important clinical consequences, resulting in significant costs to the health system (Anacleto, et al., 2007). Medication errors can be classified into several types, such as wrong dose (higher, lower, extra dose), inadequate prescription drug (inappropriate medication for older adults, medical condition, or drug-drug interaction), wrong frequency of administration, lack of patient adherence, and wrong treatment duration (Aronson, 2009).

Despite this context to tackle the prevalence of NPDs and the use of psychotropic drugs, only a few studies assessed the consumption profile and safety parameters of these drugs use. This motivates the elaboration of a study in which results can enable interventions in public health policies to improve national health care.

\section{Methodology}

This is a cross-sectional study involving patients whose psychotropic drugs were dispensed by pharmacies owned by the Brazilian National Health System, both in primary and secondary non-neuropsychiatric health care. This 12 months study took place in a 234,937-inhabitant city located in the Midwest of the State of Minas Gerais, Brazil.

The study was approved by the Federal University of São João Del-Rei Ethics Committee on Human Research and registered under the study identification 164,619. The research was conducted according to the guidelines in the Declaration of Helsinki and the Brazilian National Health Council (466/2012). The researchers declared no conflict of interest in the conduct and dissemination of the present study.

Drug dispensing information was collected from the pharmaceutical management module database stored by the Brazilian National Health System (NHS), and from a secondary city's greater area public health system health information records. Information, extraction, and encoding happened between the third and the twelfth months after the end of the 12 months study. Focused on the collected data quality, a pilot study was conducted until the concordance obtained was considered optimal and valid for its start at 0.8-1.0 Kappa (Landis, Koch, 1977).

Information regarding second-to-last psychotropic drugs dispensed to patients during the study between 12 months was analyzed. The penultimate dispensing was chosen due to the fact dose information was unavailable in the last dispensed psychotropic drugs report extracted from the NHS. 
The inclusion criterion was solely based on patients who had at least one psychotropic medicine prescription filled during the duration of the study. Patients who have not received psychotropic drugs in the same period were excluded. (Figure 1)

\section{Figure 1.}

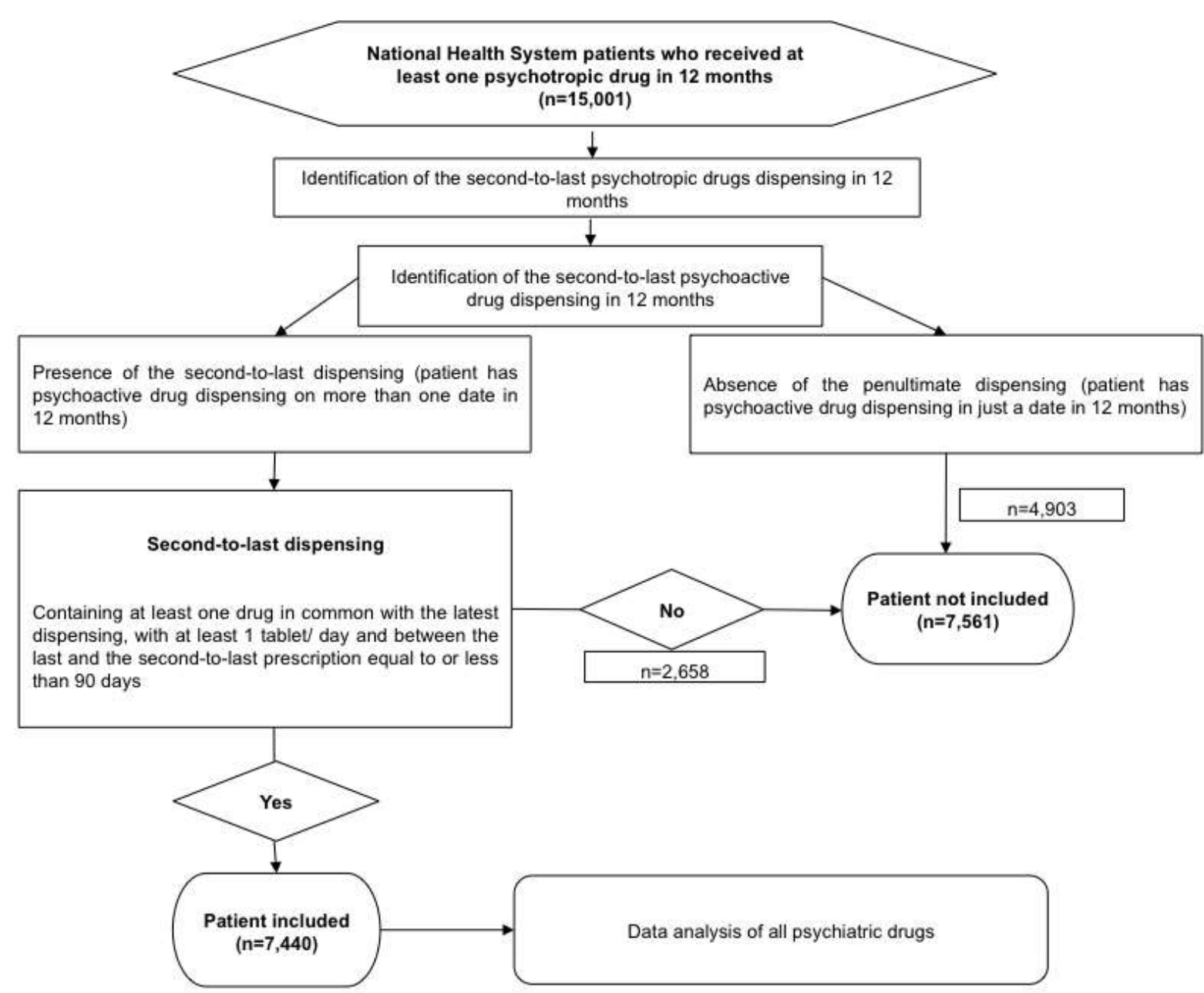

Source: Authors.

Variables such as sociodemographics, health services access/ utilization, prescriber characteristics, and pharmacotherapy safety parameters were stratified to be analysed. Prescriber's area of assistance was coded according to their clinical specialty registry in the Federal Board of Medicine, added to the National Registry of Health Care Facilities.

The potential drug interactions of clinical relevance among psychotropic drugs were based on literature available guides Drugdex and Drug interactions Facts (Tatro, 2012; Klasco RK, 2017)

Potentially inappropriate medication for the elderly (PIME) was defined according to the American Geriatrics Society (AGS) 2012 criteria (Fick et al., 2012).

The drugs listed on this guideline were Alprazolam, Amitriptyline, Clomipramine, Chlorpromazine, Clonazepam, Diazepam, Phenobarbital, Flurazepam, Haloperidol, Thioridazine, and Imipramine. Nitrazepam, which is not available in the United States market, was considered for this study as a PIME due to its 20 hours half-life (Faustino, Martins, Jacob-Filho, 2011; Klasco RK, 2017). 
Analysis consisted of descriptive statistics measuring proportion, central tendency, and variability. Bivariate and multivariate analysis was conducted to assess the association between the explanatory variables and the response variable, concerning prescribers' clinical management of patients. Groups were stratified by "patients with a psychiatrist prescriptions", "patients with shared prescription" (psychiatric and other specialties), and "patients with a prescription from other medical specialties". This analysis applied the theory of statistical learning algorithm Exhaustive CHAID (Chi-squared Automatic Interaction Detector) with a chi-square Pearson test adjusted through the Bonferroni method with cross-validation using 10 subsamples and a minimum of 100 cases for parent node and 50 for child nodes. Additionally, for the multivariate analysis, a maximum of three hierarchical levels was stipulated. A significance level of 5.0\%, epidemiological validity, and biological plausibility were considered as inclusion criteria. The Statistical Package for Social Sciences (SPSS Inc., Chicago, IL, USA) was used to perform analysis.

\section{Results and Discussion}

In the studied city, a total of 15,001 patients used at least one psychotropic in prescriptions filled at pharmacies from the public network in a 12 months study. Considering the population of 218,509 inhabitants, the prevalence was $6.9 \%$ (Brasil, 2014). From this group, a total of 7,440 patients met the inclusion criteria (Figure 1). Women made up the majority of patients $(67.1 \%)$, and the age average was 51 years old ranging from 0 to 112 years (Table 1$)$.

Concerning health service access and utilization, $54.2 \%$ of patients had multiple prescribers over time, but only one during the monitored dispensing period. The dispensing of medication prescribed by a psychiatrist only occurred in $17.6 \%$ of patients (Table 1). 


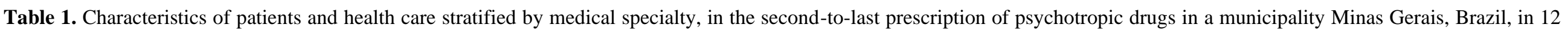
months.

\begin{tabular}{|c|c|c|c|c|c|}
\hline & $\begin{array}{c}\text { Total } \\
(n=7,440)\end{array}$ & $\begin{array}{l}\text { Patients with prescription } \\
\text { by non-psychiatrist } \\
(\mathrm{n}=6,029 ; 81,0 \%)\end{array}$ & $\begin{array}{c}\text { Patients with prescriptions by a } \\
\text { psychiatrist } \\
(n=1,310 ; 17,6 \%,)\end{array}$ & $\begin{array}{l}\text { Patients with shared } \\
\text { prescriptions }{ }^{1} \\
(n=101,1,4 \%)\end{array}$ & $P$ value \\
\hline \multicolumn{6}{|l|}{ Sociodemographic variables } \\
\hline \multicolumn{6}{|l|}{ Sex \% (number) } \\
\hline Female & $67.1(4,886)$ & $69.1(4,078)$ & $58.0(743)$ & $66.3(65)$ & \multirow{2}{*}{$<0.01$} \\
\hline Male & $32.9(2,398)$ & $30.9(1,826)$ & $42.0(539)$ & $33.7(33)$ & \\
\hline \multicolumn{6}{|l|}{ Age } \\
\hline P50 (P25;P75;range) & $51.0(39.0 ; 62.2 ; 0-112)$ & $52.0(39.0 ; 64.0 ; 0-112)$ & $48.0(37.0 ; 56.0 ; 14-90)$ & $50.0(38.0 ; 61.0 ; 23-81)$ & \multirow{4}{*}{$<0.01$} \\
\hline$<18 \%$ (number) & $5.4(404)$ & $6.7(401)$ & $0.2(3)$ & $0.0(0)$ & \\
\hline $18-64 \%$ (number) & $70.4(5,507)$ & $70.2(4,235)$ & $90.4(1,184)$ & $87.1(88)$ & \\
\hline$\geq 65 \%$ (number) & $20.6(1,529)$ & $23.1(1,393)$ & $9.4(123)$ & $12.9(13)$ & \\
\hline \multicolumn{6}{|l|}{ Health service access and utilization } \\
\hline \multicolumn{6}{|l|}{ Prescriber\% (number) } \\
\hline $\begin{array}{l}\text { Multiple prescribers over time but only } \\
\text { one during the analyzed dispensing } \\
\text { period }\end{array}$ & $54.2(4,034)$ & $55.5(3,344)$ & $51.5(675)$ & $14.9(15)$ & \multirow{3}{*}{$<0.01$} \\
\hline Only one prescriber & $40.6(3,022)$ & $39.8(2,401)$ & $46.9(616)$ & $0.0(0)$ & \\
\hline $\begin{array}{l}\text { Multiple prescribers over time and } \\
\text { analyzed dispensing }\end{array}$ & $5.2(384)$ & $4.7(284)$ & $1.5(19)$ & $85.1(86)$ & \\
\hline
\end{tabular}


Research, Society and Development, v. 10, n. 15, e455101522971, 2021

(CC BY 4.0) | ISSN 2525-3409 | DOI: http://dx.doi.org/10.33448/rsd-v10i15.22971

\section{Number of psychotropic drugs per patient}

\begin{tabular}{|c|c|c|c|c|c|}
\hline P50 (P25;P75;range) & $1.0(1.0 ; 2.0 ; 1-12)$ & $1.0(1.0 ; 2.0 ; 1-8)$ & $3.0(2.0 ; 4.0 ; 1-10)$ & $4.0(3.0 ; 5.0 ; 2-12)$ & \multirow{6}{*}{$<0.01$} \\
\hline Monotherapy \% (number) & $54.7(4,066)$ & $64.1(3,862)$ & $15.6(204)$ & $0.0(0)$ & \\
\hline Dual therapy \% (number) & $25.9(1,930)$ & $25.5(1,536)$ & $28.8(377)$ & $16.8(17)$ & \\
\hline Triple therapy \% (number)) & $10.7(795)$ & $6.7(401)$ & $28.3(371)$ & $22.8(23)$ & \\
\hline Quadruple therapy \% (number) & $5.0(372)$ & $2.3(141)$ & $15.7(206)$ & $24.8(25)$ & \\
\hline Polymedication \% (number) & $3.7(277)$ & $1.5(89)$ & $11.5(152)$ & $35.6(36)$ & \\
\hline \multicolumn{6}{|l|}{ Multiple dates \% (number) } \\
\hline No & $92.7(6,897)$ & $93.5(5,639)$ & $94.0(1,231)$ & $26.7(27)$ & \multirow{2}{*}{$<0.01$} \\
\hline Yes & $7.3(543)$ & $6.5(390)$ & $6.0(79)$ & $73.3(74)$ & \\
\hline \multicolumn{6}{|l|}{ Pharmacotherapy safety parameters } \\
\hline \multicolumn{6}{|c|}{ Patient with at least one potential drug interaction $\%$ (number) } \\
\hline No & $90.5(6,731)$ & $90.6(5,460)$ & $90.8(1,190)$ & $80.6(83)$ & \multirow{2}{*}{$<0.01$} \\
\hline Yes & $9.5(709)$ & $9.4(569)$ & $9.2(120)$ & $19.4(20)$ & \\
\hline $\begin{array}{l}\text { Inappropriate medications for older } \\
\text { adults\%(number) }\end{array}$ & $(n=1,529)$ & $(n=1,393)$ & $(n=123)$ & $(n=13)$ & \\
\hline Yes & $71.5(1,093)$ & $30.7(428)$ & $93.5(115)$ & $100.0(13)$ & \multirow{2}{*}{$<0.01$} \\
\hline No & $28.5(436)$ & $69.3(965)$ & $6.5(8)$ & $0.0(0)$ & \\
\hline
\end{tabular}

Source: Authors. 
Concerning the pharmacotherapy safety parameters, $9.5 \%$ of patients had at least one potential drug interaction of clinical importance (PCI). Interactions between benzodiazepines and antidepressants were the most frequent, followed by anticonvulsants.

In the shared prescriptions group, we observed a significant increase in the number of psychotropic drugs dispensed with an average of 4 drugs per patient. $35.6 \%$ of the studied sample underwent psychotropic polypharmacy, receiving more than 5 medicines. A total of 13,340 prescriptions were analysed aiming to identify the pharmacological subgroups profile. Considering the Anatomical Therapeutic Chemical Code (ATC), the classes of psychotropic drugs more often dispensed were anticonvulsants representing $39.3 \%$ of drugs observed, followed by antidepressants (30.8\%) and antipsychotics (12.1\%). Psychiatrists equally prescribed anticonvulsants more frequently, differing on the other classes' distribution having antipsychotics second in the ranking, followed by antidepressants. Clinicians from different specialties prescribed in first place anticonvulsants, antidepressants in second, and anxiolytics in third (Table 2).

Table 2. Frequency of psychotropic and pharmacological subgroups according to the presence of the Psychiatrist prescribing in a municipality greater area Minas Gerais, Brazil, 12 months observation.

\begin{tabular}{|c|c|c|c|c|}
\hline & $\begin{array}{c}\text { Total } \\
(n=13,340)\end{array}$ & $\begin{array}{l}\text { Prescriptions by } \\
\text { psychiatrist } \\
(n=3,719)\end{array}$ & $\begin{array}{l}\text { Shared prescription } \\
\qquad(\mathrm{n}=\mathbf{4 4 1})\end{array}$ & $\begin{array}{c}\text { Prescriptions by non- } \\
\text { psychiatrist } \\
(\mathbf{n}=9,180)\end{array}$ \\
\hline Pharmacological subgroup & $\%$ (number) & $\%$ (number;ranking) & $\%$ (number;ranking) & $\%$ (number;ranking) \\
\hline Antiepileptics & $39.3(5,238)$ & $31.2(1,162 ; 1)$ & $32.7(144 ; 1)$ & $42.8(3,932 ; 1)$ \\
\hline Antidepressants & $30.8(4,108)$ & $19.7(731 ; 3)$ & $19.3(85 ; 3)$ & $35.9(3,292 ; 2)$ \\
\hline Antipsychotics & $12.1(1,609)$ & $24.5(913 ; 2)$ & $24.0(106 ; 2)$ & $6.4(590 ; 4)$ \\
\hline Anxiolytics & $10.0(1,338)$ & $10.1(375 ; 4)$ & $9.8(43 ; 4)$ & $10.0(920 ; 3)$ \\
\hline Anticholinergic agents & $4.2(565)$ & $8.6(318 ; 5)$ & $8.4(37 ; 5)$ & $2.3(210 ; 6)$ \\
\hline Hypnotics and sedatives & $3.6(482)$ & $5.9(220 ; 6)$ & $5.9(26 ; 6)$ & $2.6(236 ; 5)$ \\
\hline Psychotropic & $\%$ (number) & $\%$ (number.;ranking) & $\%$ (number;ranking) & $\%$ (number;ranking) \\
\hline Clonazepam & $13.9(1,874)$ & $15.3(569 ; 1)$ & $15.0(66 ; 1)$ & $13.4(1,239 ; 1)$ \\
\hline Carbamazepine & $8.8(1,174)$ & $5.5(206 ; 5)$ & $7.5(33 ; 5)$ & $10.2(935 ; 4)$ \\
\hline Fluoxetine & $8.8(1,173)$ & $3.6(134 ; 11)$ & $3.4(15 ; 10)$ & $11.2(1024 ; 2)$ \\
\hline Amitriptyline & $8.2(1,096)$ & $3.3(122 ; 12)$ & $2.9(13 ; 12)$ & $10.5(961 ; 3)$ \\
\hline Diazepam & $8.1(1,087)$ & $8.5(315 ; 4)$ & $7.7(34 ; 4)$ & $8.0(738 ; 5)$ \\
\hline Phenobarbital & 5.7 (767) & $2.0(75 ; 18)$ & $1.6(7 ; 16)$ & $7.5(685 ; 6)$ \\
\hline
\end{tabular}




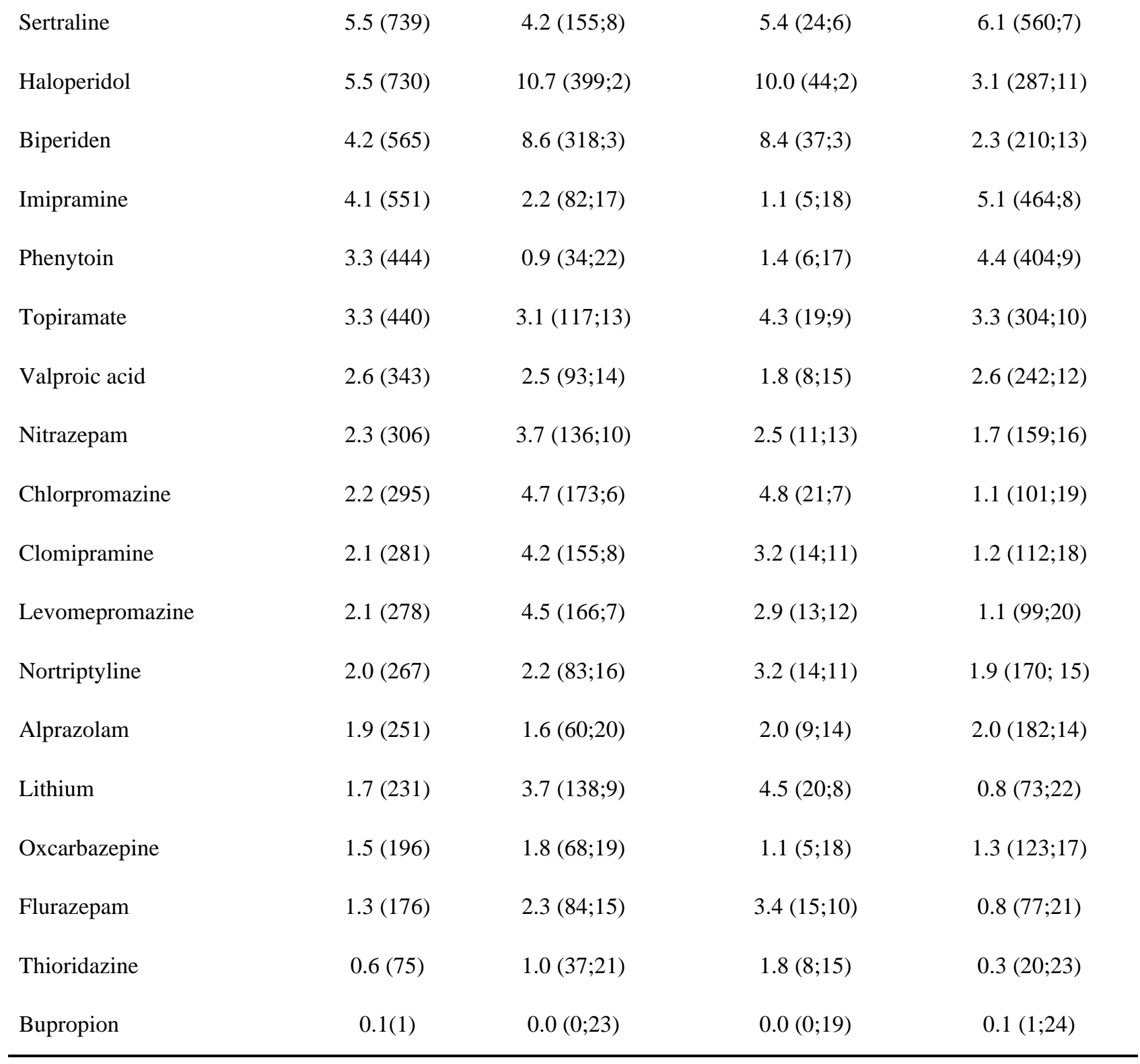

Source: Authors.

The use of anticonvulsants may be overestimated because the prevalence of epilepsy and seizure disorders is not consistent with the more prevalent morbidity among NPD. In our study, after removing the contribution of clonazepam as an anticonvulsant, antidepressants would figure as the major class, similar to the nosological prevalence of the NPD and their respective treatments. Besides, benzodiazepines were the most prescribed psychotropic (27.7\%) both among psychiatrists (37.3\%) and other specialties (26.1\%). The ATC classification categorizes clonazepam as an anticonvulsant however, this and other benzodiazepines are mainly clinically chosen as anxiolytic or hypnotic, rather than a first-line anticonvulsant described in treatment protocols (Lader, Tylee, Donoghue, 2009; Hedenrud, Svensson, Wallerstedt, 2013; Rocha, Werlang, 2013; Klasco RK, 2017).

Another relevant finding was that, for two or more drugs, the second hierarchical level was the clinical management shared between the psychiatrist and other prescribers. For patients undergoing mono-therapy, age was the second most important variable ( $\mathrm{p}<0.01$ ), especially at the extremes of age, when drugs prescribed only by psychiatrists were proportionally reduced. 
This study brings for the first time to literature the clear idea of the use of psychotropic pharmacotherapy within the Brazilian National Health System addressing important risks to the population assisted by non psychiatrist physicians in mediumsized municipalities greater areas. The study can also subsidize public health interventions on pharmaceutical management. While the prevalence of the psychotropic' medicines use is similar to the one found in previous Brazilian studies, it is likely to be underestimated as a nongovernmental health system network dispensing is not taken into account (Quintana et al., 2013; Rocha, Werlang, 2013; Rodrigues, Facchini, Lima, 2019). The literature shows that the consumption of psychotropic drugs is more prevalent in women, and several factors may explain this finding, such as the greater use of health services and the higher prevalence of affective disorders in women. This proportion is greater when compared to other studies and may reflect the growing trend of care specialization and its demands as well as the number of professionals available (Andrade, Andrade, Santos, 2004; Bianchi, Bianchini, Scanavacca, 2011; Quintana et al., 2013; Rodrigues, Facchini, Lima, 2019). However, the Brazilian scenario appears to have a greater portion of women using psychotropic medications in comparison to men. In a similar study performed in a psychiatry outpatient in the Indian population, women represented $51.8 \%$ and men $48.2 \%$ (Thakkar et al., 2013).

Our study highlights the fact two nurses and one dental surgeon were detected during the analysis as prescribers, disagreeing with the Brazilian Ministry of Health ordinance number 344/1998, which only allows professionals registered on Boards of Dentistry to prescribe a small scope of psychotropic drugs such as benzodiazepines and antidepressants. On the other hand, nurses are in no circumstances allowed to prescribe any psychotropic drug (Brasil, 1998).

Most patients (92.7\%) received all of their medication in a single day with one medication per patient as the median value and amplitude of 1 to 12 psychotropic drugs (Table 1). Similar value in 2013 was found of 1.5 psychotropic drugs per patient in a Family Health Unit in Porto Alegre, Brazil (Rocha, Werlang, 2013).

A review on polypharmacy in neuropsychiatric practice addressed the combination of a selective serotonin reuptake inhibitor and benzodiazepines as the most common among psychotropic drugs, followed by tricyclic antidepressant and benzodiazepine. This may explain the higher frequency of PCI involving benzodiazepines and antidepressants. According to the AGS classification at least one PIME was identified in $71.5 \%(n=1,529)$ of older adults (Table 1). Although significant, the high prevalence of PIME was similar to what has been recently published in other studies when it ranged from 62.4-62.5\% (Lai et al., 2009; Popović et al., 2009; Kukreja et al., 2013).

Medication errors are consistently studied and reported in literature configuring a major public health problem (Anacleto, et al., 2005; Aquino, 2008; Rosa et al., 2009). Medication errors are preventable events that may lead to inappropriate medication use resulting in harm to the patient's health condition. Improving prescription practices within the national health system is essential to reduce such occurrences (Correr, et al., 2009).

PCI had increased statistically significantly by approximately $10 \%$. This scenario suggests that delegating patients to care for more than one health professional generates a greater risk on pharmacotherapy safety due to the lack of communication among physicians of different clinics, dysfunctional patient data recording, previous therapy management, or even diagnosis (Machado, Colomé, Beck, 2011). In an Indian psychiatric outpatient, the average number of psychotropic drugs in 2012 per prescription was 1.79, less than half the Brazilian National Health System prescribers from the studied city greater area requested, confirming the increase observed in shared prescriptions or non-psychiatrist ones (Thakkar et al., 2013).

These findings corresponded to the similar trend observed previously that reported the fact anxiolytics and antidepressants were the most prescribed by general practitioners, endocrinologists, and gynecologists, while anticonvulsants and antipsychotics were more prevalent among psychiatrists and neurologists (Andrade, Andrade, Santos, 2004). These findings appear to underline some nosological spectrum that is differently addressed by each specialty with specific pharmacotherapy (Hedenrud, Svensson, Wallerstedt, 2013; Rodrigues, Facchini, Lima, 2019). 
Among anticonvulsants, the use of Phenobarbital stands out as the third most prescribed anticonvulsant with the exclusion of prescriptions by psychiatrists and shared prescriptions (psychiatrists and non-psychiatrists) being the fifth most prescribed anticonvulsant. Phenobarbital and other barbiturates are effective in controlling seizures and have been used in the past as first-line treatments for many forms of epilepsy. However, they often cause sedation, ataxia, mental confusion, dizziness, decreased libido, and depression in adults as well as hyperactivity, irritability, sleep disorders, and an apparent decrease in IQ in children. Thus, its use should be limited to situations in which there are no other treatment alternatives. In this study, the high prevalence of this medication use is related to its low cost and availability in the city pharmacies, which fills in prescriptions at no cost to the patient.

Using multivariate data analysis (Figure 2), considering the "clinical management of patients concerning their prescribers", the explanatory variable at the first hierarchical level was the number of medications $(p<0.01)$. As the number of medications increased, the proportion of total prescriptions by psychiatrists and prescriptions shared between a psychiatrist and other prescribers followed the same trend, reducing the contribution of "no medication prescribed by a psychiatrist". This finding is reinforced at the second hierarchical level; when patients were using three or more drugs and a single prescriber, this prescriber was a psychiatrist. Patients with a higher number of psychotropic drugs may have a more severe clinical picture and be more likely to be monitored by a specialist according to a logic system hierarchization (Hedenrud, Svensson, Wallerstedt, 2013; Brasil, 2017). 
Research, Society and Development, v. 10, n. 15, e455101522971, 2021

Figure 2.

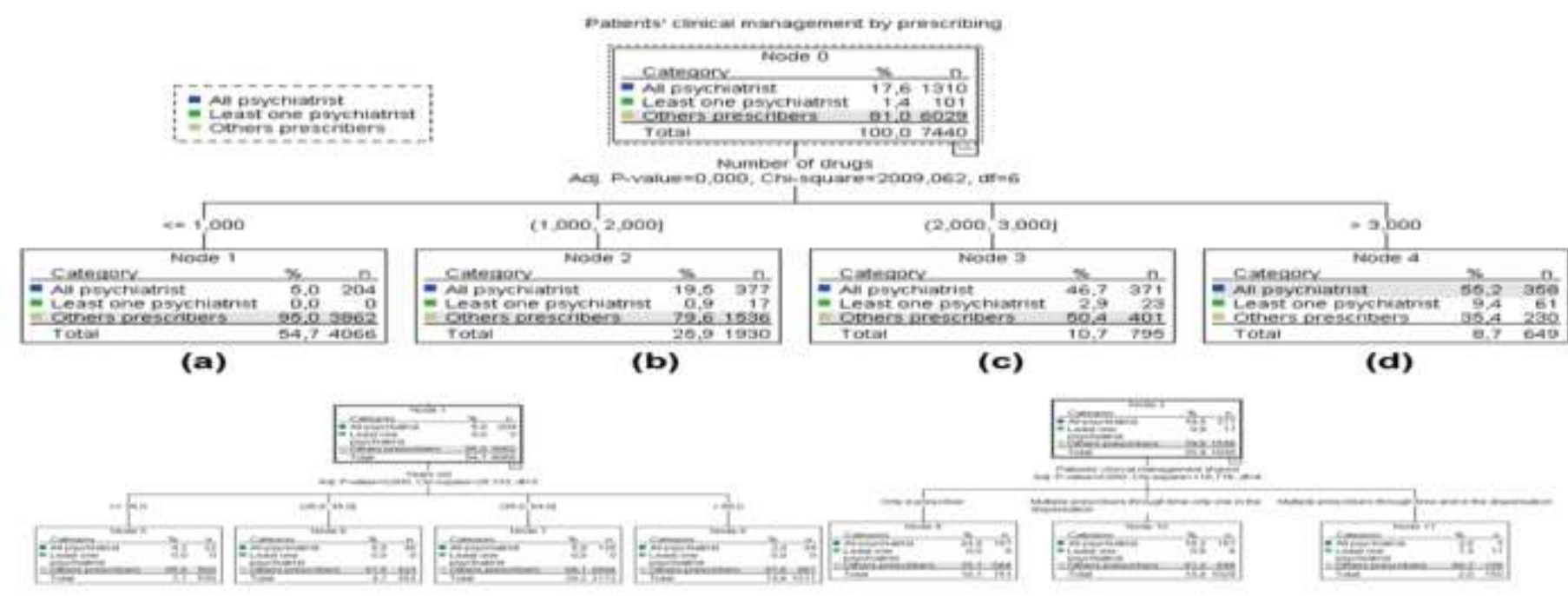

(a)

(b)

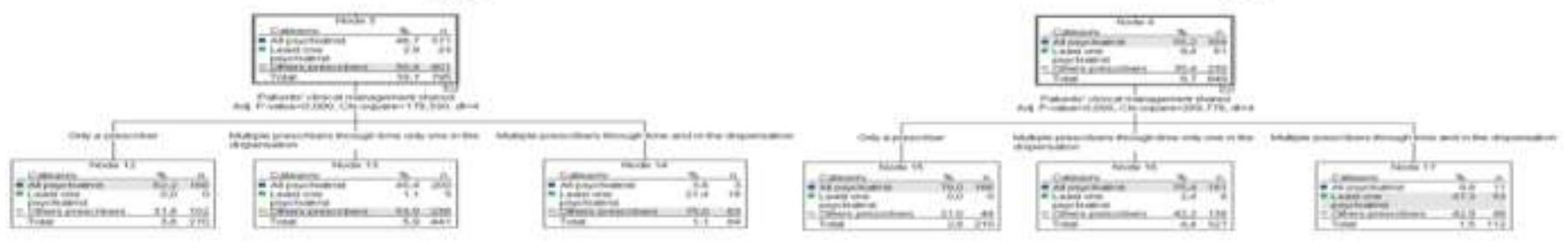

(c)

(d)

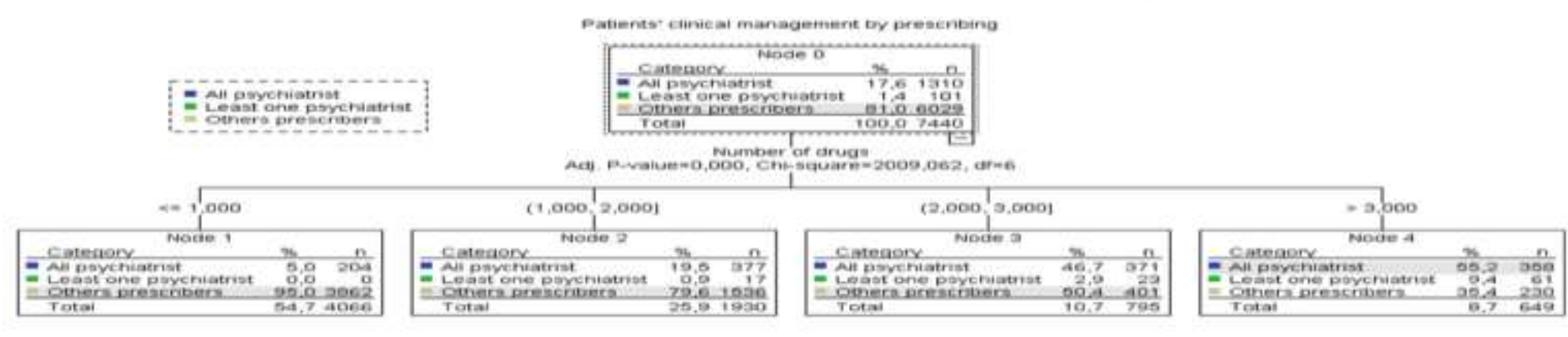

Source: Authors. 
The literature reports the difficulties faced by general practitioners in prescribing psychiatric drugs as the suspension of medication previously prescribed in one of the addressed categories, and the emotional prescription, used by the clinician to avoid friction with the patient or other health professionals (Hedenrud, Svensson, Wallerstedt, 2013).

The high prevalence of psychotropic medicine's use, although often underestimated, was unsurprisingly revealed, pointing benzodiazepines as the main selection for the pharmacotherapy by prescribers. The study detected a high occurrence of medication errors, which included drug interactions and the presence of inappropriate drugs for older adults, especially in patients with shared therapy management among practitioners. Those errors signalize the need for relevant NHS establishment of reference and counter-reference system, hierarchical attention to patient safety, and clinical pharmacy services.

The ranking of explanatory variables in the clinical management of patients indicated the number of medications in use, the age, and the shared therapeutic management among practitioners as the most relevant variable. Medical doctors and pharmacists could use such characteristics in public health to identify patients at risk of unsafe treatments throughout followups.

\section{Final Considerations}

This study main question was, “Are psychiatrist's prescriptions less risky for patients?” and as hypothesized the research proved non-psychiatrist prescriptions offer more risk to the patients in a broad range of situations. The high occurrence of medication errors, which included drug interactions and the presence of inappropriate medicines use for the elderly, those errors indicate the urgent need for NHS establishment of reference and counter-reference system and hierarchical attention to patient safety. and clinical pharmacy services.

Considering this research outcomes, when it comes to psychotropic therapies the pharmacist is the professional who throughout clinical pharmacy services can place preventive interventions and avoid iatrogenic future conditions to the patient. In this context, the NHS provision of access to patients' pharmacotherapy history (medical records) is another essential for dispensing, as such solutions connect patients' electronic records to filling up prescriptions applied technologies, allowing the professional to consult and assess accurately in order to provide greater care.

\section{Acknowledgments}

We appreciate the collaboration of the Pharmacist Thais Bueno Enes dos Santos, technical reference from the city's Pharmaceutical Management, and Mário Henrique Rabelo, a Pharmacy student at the Federal University of São João Del Rei, for database setting and upload.

\section{References}

Agência Nacional de Vigilância Sanitária (Brasil), $\mathrm{n}^{\mathrm{o}} .344$ de 12 de maio de 1998. (1998) Regulamento Técnico sobre substâncias e medicamentos sujeitos a controle especial. Diário Oficial da União 31 dez 1998; Seção 1.

Alarcon, R. D., Lolas, F., Mari, J. J., Lazaro, J., \& Bac-Baldomero, E. (2019). Latin American and Spanish-speaking perspectives on the challenges of global psychiatry. Braz J Psychiatry. 42:1.

Anacleto, T. A., Perini, E., Rosa, M. B., \& César, C. C. Drug-dispensing errors in the hospital pharmacy. Clinics (Sao Paulo). 62(3):243-50.

Anacleto, T. A., Perini, E., Rosa, M. B., \& César, C. C. (2005). Medication errors and drug-dispensing systems in a hospital pharmacy. Clinics (Sao Paulo). 60(4):325-32.

Andrade, M. F., Andrade, R. C. G., \& Santos, V. (2004). Prescrição de psicotrópicos: avaliação das informações contidas em receitas e notificações. Rev. Bras. Cienc. Farm. 40(4): 471-479.

Aquino, D. S. (2008). Por que o uso racional de medicamentos deve ser uma prioridade. Ciênc. Saúde Colet. 13:733-736.

Aronson, J. K. (2009). Medication errors: definitions and classification. Br J Clin Pharmacol. 67(6):599-604. 
Azermai, M., Elseviers, M., Petrovic, M., Van-Bortel, L., \& Vander-Stichele, R. (2011). Geriatric drug utilisation of psychotropics in Belgian nursing homes. Hum. Psychopharmacol. 26(1):12-20.

Bianchi, S., Bianchini, E., \& Scanavacca, P. (2011). Use of antipsychotic and antidepressant within the Psychiatric Disease Centre, Regional Health Service of Ferrara. BMC Clin Pharmacol. 11:21.

Brasil, Ministério da Saúde: Estudo de estimativas populacionais por município, in DATASUS. (2014).

Brasil. Instituto Brasileiro de Geografia e Estatística (2017). Banco de Tabelas Estatísticas.

Chow, W. S., \& Priebe S. (2013) Understanding psychiatric institutionalization: a conceptual review, BMC Psychiatry. 13:169.

Correr, C. J., Pontarolo, R., Wiens, A., Rossignoli, P., Melchiors, A. C., Radominski, R., et al. (2009). Arq Bras Endocrinol Metabol. 53(7):825-33.

Faustino, C. G., Martins M. A., \& Jacob-Filho W. (2011). Medicamentos potencialmente inapropriados prescritos a pacientes idosos ambulatoriais de clínica médica. Einstein (Sao Paulo). 9:18-23.

Fick, D., Semla T., Beizer J., Brandt N., Dombrowski R., DuBeau C. E., et al. (2012). American Geriatrics Society updated Beers Criteria for potentially inappropriate medication use in older adults. J. Am. Geriatr. Soc. 60(4): 616-31.

Guerra, C. S., Herculano M. M., Filha M. O., Dias M. D., Cordeiro R. C., \& Araújo V. S. (2013). Epidemiologic profile, and prevalence of psychotropic use in one reference unit for mental health. J Nurs UFPE on line. 7:6.

Hasan S. S., Zaidi S. T. R., Nirwan J. S., Ghori M. U., Javid F., \& Ahmadi K. (2019). Use of Central Nervous System (CNS) Medicines in Aged Care Homes: A Systematic Review and Meta-Analysis. J. Clin. Med. 8(9):1292.

Hedenrud T. M., Svensson S. A., \& Wallerstedt S. M. (2013). "Psychiatry is not a science like others" - a focus group study on psychotropic prescribing in primary care. BMC Fam Pract. 14:115.

Klasco R. K., DRUGDEX® System (2017). Thomson Micromedex Publishing.

Kukreja S., Kalra G., Shah N., Shrivastava A. (2013). Polypharmacy in psychiatry: a review. Mens Sana Monogr. 11(1):82-99.

Lader M., Tylee A., \& Donoghue J. (2009). Withdrawing benzodiazepines in primary care. CNS Drugs. 23(1):19-34.

Lai H., Hwang S., Chen Y., Chen T., Lin M., \& Chen L. (2009). Prevalence of the prescribing of potentially inappropriate medications at ambulatory care visits by elderly patients covered by the Taiwanese National Health Insurance program. Clin Ther. 31(8):1859-70.

Landis J. R., \& Koch G. G. (1977). The measurement of observer agreement for categorical data. Biometrics. 33(1):159-74.

Machado L. M., Colomé J. S., \& Beck C. L. C. (2011). Estratégia de Saúde da Família e o sistema de referência e de contrarreferência: um desafio a ser enfrentado. R. de Enferm. UFSM. 1:1.

Popović B., Quadranti N. R., Matanović S. M., Lisica I. D., Ljubotina A., Duliba D. P., et al. (2014). Potentially inappropriate prescribing in elderly outpatients in Croatia. Eur J Clin Pharmacol. 70(6):737-44.

Quintana M. I., Andreoli S. B., Moreira F. G., Ribeiro W. S., Feijo M. M., Bressan R. A., Coutinho E. S., \& Mari J. J. (2013). Epidemiology of psychotropic drug use in Rio de Janeiro, Brazil: gaps in mental illness treatments. PLoS One. 8(5):e62270.

Rocha B. S., \& Werlang M. C. (2013). Psicofármacos na Estratégia Saúde da Família: perfil de utilização, acesso e estratégias para a promoção do uso racional. Ciênc. Saúde Colet. 18(11):3291-3300.

Rodrigues M. A. P., Fachinni L. A. \& Lima M. S. (2006). Modificações nos padrões de consumo de psicofármacos em localidades do Sul do Brasil. Rev Saúde Públ. 40(1):107-114.

Rosa M. B., Perini E., Anacleto T. A., Neiva H. M., \& Bogutchi T. (2009). Erros na prescrição hospitalar de medicamentos potencialmente perigosos. Rev. Saúde Públ. 43(3):490-8.

Schmidt I. M., Duncan B. B., Silva G. A., Menezes A. M., Monteiro C. A., \& Barreto S. M. (2011). Chronic non-communicable diseases in Brazil: burden and current challenges. Lancet. 377(9781):1949-61.

Tatro D. S. (2012). Drug Interactions Facts 2013: The Authority on Drug Interactions, Ed L. W. Wilkins.

Thakkar K. B., Jain M. M., Billa G., Joshi A., \& Khobragade A. A. (2013). A drug utilization study of psychotropic drugs prescribed in the psychiatry outpatient department of a tertiary care hospital. J Clin Diagn Res. 7(12):2759-64.

Wagner G. A., \& Andrade A. D. (2010). Pharmacist professionals in the prevention of drug abuse: updating roles, and opportunities. Braz. J. Pharm. Sci. 46(1):19-27.

World Health Organization (2021). Department of Mental Health and Substances Abuse: WHO Reports. World Health Organization. 